\title{
Peripheral metabolic actions of leptin
}

\author{
Michael A. Cawthorne*, Nicholas M. Morton, Anna L. Pallett, Yong-Ling Liu and Valur Emilsson \\ Clore Laboratory, University of Buckingham, Hunter Street, Buckingham MK18 1EG, UK
}

The $o b$ gene product, leptin, is produced predominantly in adipose tissue. In $o b / o b$ mice, a mutation in the $o b$ gene prevents normal leptin production and results in a phenotype characterized by obesity and diabetes (Zhang et al. 1994). Daily injections of recombinant leptin to $o b / o b$ mice inhibit food intake and reduce body weight and fat mass (Campfield et al. 1995; Halaas et al. 1995; Pelleymounter et al. 1995). This treatment also normalizes the blood glucose concentration and reduces the plasma insulin concentration of $o b / a b$ mice (Pelleymounter et al. 1995). It was possible that the changes in glycaemia and insulin sensitivity in $o b / o b$ mice given leptin might be a simple consequence of the antiobesity action. However, in pair-feeding studies, infusion of leptin not only resulted in a greater reduction in body fat than in the pair-fed mice, but the reduction in the plasma insulin concentration was much greater than that produced by an equivalent reduction in food intake (Levin et al. 1996). These findings suggested to us that leptin might have direct effects on a number of peripheral tissues associated with energy metabolism, including the endocrine pancreas and skeletal muscle.

The leptin receptor (OB-R) is the product of the diabetes (db) gene (Chen et al. 1996; Lee et al. 1996) and was initially isolated as a complementary DNA (cDNA) from the choroid plexus cDNA library, encoding an 894 amino acid cell surface receptor which includes a hydrophobic signal sequence (Tartaglia et al. 1995). Structurally, OB-R is related to the class I cytokine receptor family, which includes gp 130, the common signal transducing chain for interleukin-6, leukaemia inhibitory factor receptor $\alpha$-chain and the granulocyte colony-stimulatory factor. However, the interleukin-6, leukaemia inhibitory factor and granulocyte colony-stimulatory factor receptors all contain sequence motifs in the cytoplasmic domain that are required for interaction with janus kinase (JAK) and signal transduction and activation of transcription (STAT), whilst the OB-R from the choroid plexus lacks such a sequence. Further investigation showed that there are multiple isoforms of the OB-R, and a long form of the receptor $(\mathrm{OB}-\mathrm{Rb})$ was identified in the hypothalamus. It contained a long cytoplasmic domain of 302 amino acids, including consensus docking sites for JAK and STAT (Chen et al. 1996; Lee et al. 1996). The different isoforms of OB-Ra and $\mathrm{OB}-\mathrm{Rb}$ are generated by alternative splicing, and additional short carboxyl terminal splice variants (OB-Rc, $\mathrm{OB}-\mathrm{Rd}$ ) and a soluble isoform lacking a transmembrane domain (OB-Re) have been identified also.
The importance of the $\mathrm{OB}-\mathrm{Rb}$ isoform in the action of leptin was demonstrated by the finding of a point mutation ( $\mathrm{G} \rightarrow \mathrm{T}$ transversion) in $d b / d b$ mice which results in a new splice donor site and, hence, a premature termination of translation (Chen et al. 1996; Lee et al. 1996). This truncated OB-R $(d b)$ isoform lacks the sequence motif required for JAK and STAT interaction and so $d b / d b$ mice do not respond to leptin.

\section{Effect of leptin on insulin secretion}

Kieffer et al. (1996) were the first to report on the presence of OB-R in rat pancreatic islets and the mouse clonal $\beta$-TC 3 cell line and found evidence of OB-R mRNA. However, their riboprobe could not discriminate between the mRNA of the functional $\mathrm{OB}-\mathrm{Rb}$ isoform and the ubiquitously expressed short forms of the receptor. Despite having no functional evidence they postulated the existence of an adipo-insular axis. However, subsequent studies by Leclercq-Meyer $e t$ al. (1997) suggested that leptin did not regulate insulin secretion in the perfused rat pancreas under conditions designed to mimic postprandial glycaemia $(8.3 \mathrm{mmol} / 1$ glucose $)$, with a leptin concentration similar to that found in obese individuals $(1 \mathrm{nmol} / \mathrm{l})$. In fact, although not significant statistically, this concentration of leptin caused a mean $13 \%$ reduction in the insulin output.

If leptin has a direct action on insulin secretion, we reasoned that $\mathrm{OB}-\mathrm{Rb}$ must be expressed in pancreatic islets and that $o b / o b$ mice, which lack endogenous leptin, would be a sensitive model for detecting functional responses. An approximately 0.68 kilobase cDNA sequence that specifically encodes the cytoplasmic domain of the leptin receptor (OB-Rb) was used to assess expression. By the use of reverse transcription-polymerase chain reaction, followed by DNA-specific hybridization, OB-Rb expression was detected in the hypothalamus and to a lesser degree in several tissues, including pancreatic islets. This was confirmed using the less-sensitive RNA blot hybridization (Emilsson et al. 1997). We have also demonstrated the presence of the $\mathrm{OB}-\mathrm{Rb}$ in normal lean mouse islets, in rat islets (Pallett et al. 1997) and in RIN m5F cells (Islam et al. 1997). In rat islets we found, using quantitative reverse transcriptionpolymerase chain reaction amplification of cDNA from three islets, that $\mathrm{OB}-\mathrm{Rb}$ could be detected, and constituted $10 \%$ or less of the OB-R isoforms.

\footnotetext{
Abbreviations: cDNA, complementary DNA; JAK, janus kinase; OB-R, leptin receptor; OB-Rb, long form of OB-R; OB-Ra,c,d,e, multiple isoforms of OB-R; STAT, signal transduction and activation of transcription.

*Corresponding author: Professor Michael A. Cawthorne, fax +44 (0)1280 820261, email mac@buck.ac.uk
} 
The first evidence of a direct inhibitory effect of leptin on insulin secretion came from studies in $a b / o b$ mice (Emilsson et al. 1997). Leptin (100 nmol/l) significantly reduced the rate of basal insulin secretion following direct administration to the perfused pancreas preparation (Fig. 1). No such effect was found in the perfused pancreas of the hyperinsulinaemic Zucker $f a / f a$ rat, which has a point mutation in the extracellular domain and is markedly less sensitive to the anti-obesity effects of leptin. Leptin (1-100 nmol/l) inhibited in a dosedependent manner the stimulatory effects of $16.7 \mathrm{mmol}$ glucose/l on insulin secretion by isolated islets from $o b / o b$ mice, with a half-maximal inhibitory response of approximately $10 \mathrm{nmol} / \mathrm{l}$ (Fig. 2). A similar half-maximal response

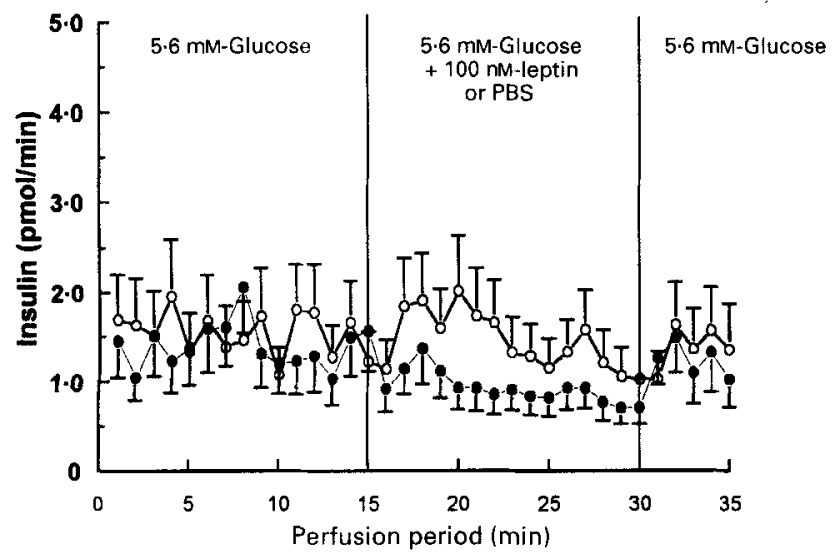

Fig. 1. Effect of murine leptin $(100 \mathrm{nmol} / \mathrm{l})$ on basal insulin release from the isolated perfused pancreas of ob/ob mice. (o), Control; (•), leptin. The mean insulin output during the leptin treatment period was significantly reduced relative to that of the control $(P<0.05)$.

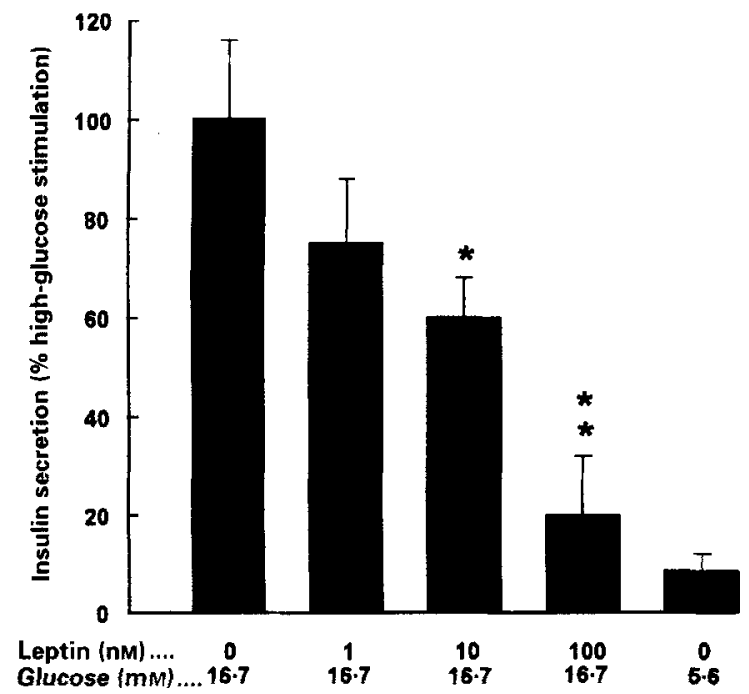

Fig. 2. Dose dependency of inhibitory effects of recombinant murine leptin on glucose-stimulated $(16.7 \mathrm{mmol} / \mathrm{l})$ insulin secretion from isolated pancreatic islets of $o b / o b$ mice. Values are expressed as percentages of mean high-glucose control with their standard errors represented by vertical bars for more than ten islets. Basal rate of insulin secretion is 0.45 (SEM 0.19) pmol insulin/2 h from ten islets, and the glucose-stimulated rate is 5.24 (SEM 1.57) $\mathrm{pmol} / 2 \mathrm{~h}$ from ten islets. Mean values were significantly different from that for $16.7 \mathrm{~mm}$-glucose and zero leptin: ${ }^{*} P<0.05,{ }^{* *} P<0.01$. occurred in normal mice, but insulin secretion in islets from $d b / d b$ mice was unaffected by $100 \mathrm{nmol}$ leptin/l. Thus, it was concluded that leptin was acting directly and the effect was mediated by the functional long-form of the receptor $\mathrm{OB}-\mathrm{Rb}$.

The concentrations of leptin used in these studies were high $(160-1600 \mathrm{ng} / \mathrm{ml})$ relative to the physiological concentration of leptin, which is generally in the range $1-100 \mathrm{ng} / \mathrm{ml}$ in human subjects and in rodents. However, it is clear that the potency of recombinant leptin from various sources is variable, with the dose causing a $50 \%$ reduction in food intake in an $o b / o b$ mouse varying from 0.1 to $5 \mathrm{mg} / \mathrm{kg}$ (LA Campfield, personal communication). Thus, exogenous recombinant leptin may be considerably less potent than endogenously-released leptin.

In order to clarify whether the earlier failure of LeclercqMeyer et al. (1997) to demonstrate a response in rats might indicate a species difference in leptin action, we investigated the effect of leptin on glucose-induced insulin secretion in isolated islets from rats. Leptin $(0 \cdot 1-100 \mathrm{nmol} / \mathrm{l})$ inhibited insulin secretion but not in a dose-dependent manner (Pallett et al. 1997). Thus, both 1 and $10 \mathrm{nmol}$ leptin/l produced significant inhibitory responses $(P<0.05)$, but at the higher concentration of leptin $(100 \mathrm{nmol} / \mathrm{l})$ and the lowest concentration $(0.1 \mathrm{nmol} / \mathrm{l})$ there was no significant inhibition (Fig. 3). This ' $U$ '-shaped dose response has been noted in studies examining leptin action on luteinizing hormone release from the rat anterior pituitary (Yu et al. 1997). Class 1 cytokine receptors, which include $\mathrm{OB}-\mathrm{Rb}$, lack intrinsic tyrosine kinase ( $E C$ 2.7.1.112) activity and are activated by ligand-induced receptor homo- or hetero-dimerization or oligomerization before activation of receptor-associated kinases of the JAK family. OB-Rb oligomerizes with itself (Baumann et al. 1996; Nakashima et al. 1997; White et al. 1997). We suggest that high concentrations of leptin might prevent oligomerization and, hence, induce desensitization.

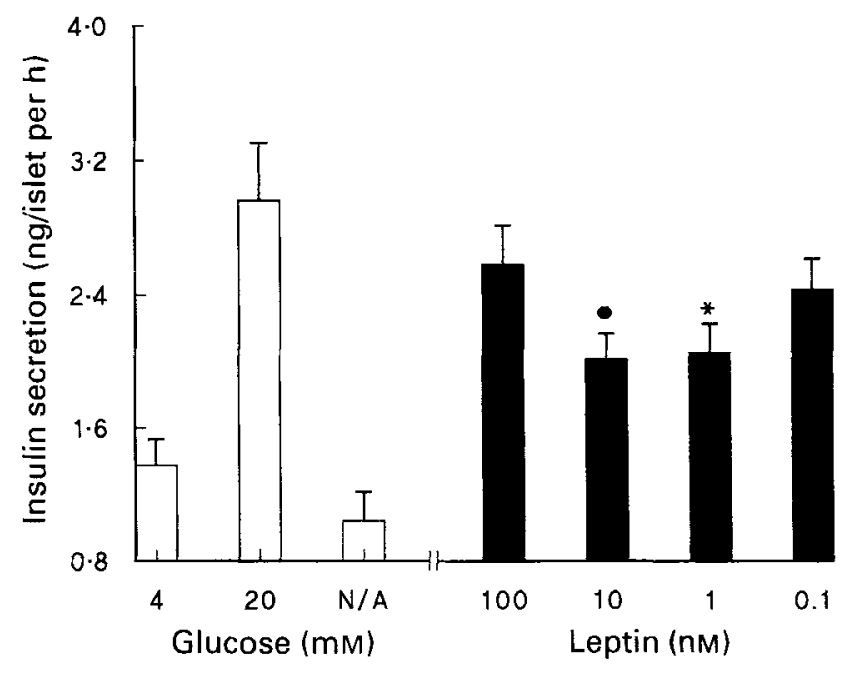

Fig. 3. Dose-dependent effect of leptin $(100-0.1 \mathrm{nmol} / \mathrm{l})$ on glucose-stimulated $(20 \mathrm{mmol} / \mathrm{l})$ insulin secretion from isolated rat islets of Langerhans. Noradrenaline (N/A) was used as a positive control. Values are means with their standard errors represented by vertical bars. Mean values were significantly different from that for 20 mmol glucose $/ \mathrm{l}$ control: ${ }^{*} P<0.05$. 
The finding that murine leptin will inhibit insulin secretion by rat islets has recently been confirmed by Bloom and his colleagues (Kulkarni et al. 1997). More importantly, these authors have shown also that mouse leptin at concentrations within the physiological range will inhibit insulin secretion by human islets.

\section{Mechanism of leptin action on insulin secretion}

Kinetic analysis of the effects of leptin on insulin secretion has shown an effect on the $o b / o b$ mouse perfused pancreas (Emilsson et al. 1997) and isolated rat islets (Pallett et al. 1997) within $5 \mathrm{~min}$, with a similar time-lag after withdrawal of leptin. Although we have shown an inhibitory effect on basal insulin secretion in the perfused pancreas of hyperinsulinaemic hyperglycaemic $o b / o b$ mice, studies using rat islets demonstrated that the effect of leptin on insulin release only occurred at high glucose concentrations (Pallett et al. 1997). This finding has recently been confirmed by Ookuma et al. (1998). These latter authors also demonstrated that leptin did not affect the first phase of insulin secretion in response to a high glucose concentration $(16.7 \mathrm{mmol} / \mathrm{l})$ but significantly inhibited insulin release during the second phase.

The molecular mechanism(s) by which leptin inhibits insulin secretion has been the subject of several recent studies. Kieffer et al. (1997) demonstrated that leptin could hyperpolarize $o b / o b$ mouse islet $\beta$-cell membranes, leading to a reduction in intracellular $\mathrm{Ca}$. This was associated with leptin-induced opening of the ATP-sensitive $\mathrm{K}^{+}$channel and was reversible on administration of glucose or glucagon-like peptide-1. They noted that the apparent biphasic induction of the ATP-sensitive $\mathrm{K}^{+}$channel was similar to that observed for JAK 2-mediated activation of $\mathrm{K}^{+}$channels by prolactin (Prevaskaya et al. 1995). However, Ookuma et al. (1998), using rat islets, found that leptin did not inhibit glibenclamide-stimulated insulin secretion in the presence of a low glucose concentration $(3.3 \mathrm{mmol} / \mathrm{l})$. Since glibenclamide stimulates first-phase insulin secretion by acting on the ATP-sensitive $\mathrm{K}^{+}$channel to induce depolarization and stimulate the influx of $\mathrm{Ca}^{2+}$, their studies do not support leptin acting via the ATP-sensitive $\mathrm{K}^{+}$channel.

Fehmann et al. $(1997 a, b)$ found that leptin reduced the intracellular $\mathrm{Ca}^{2+}$ concentration in both mouse islets and the INS-1 cell line, but without affecting the membrane potential. This resulted, in their hands, in an inhibition of both basal and stimulated (glucose and glucagon-like peptide-1) insulin secretion.

Ookuma et al. (1998) showed that leptin will inhibit phorbol 12-myristate 13-acetate-induced increases in insulin secretion in the presence of $\mathrm{Ca}^{2+}$, but not in the absence of $\mathrm{Ca}^{2+}$. Phorbol 12-myristate 13-acetate induces insulin secretion from islets (Easom et al. 1989) and RIN m5F cells (Yada et al. 1989) by activating islet protein kinase C. It has been suggested that the impaired second phase of insulin secretion observed in animal models of hyperglycaemia and obesity (Surwit et al. 1988; Wencel et al. 1995) is associated with aberrations of $\mathrm{Ca}^{2+}$ efflux and protein kinase $\mathrm{C}$ activity (Ookuma et al. 1997). All these findings may suggest that the inhibitory effect of leptin on insulin secretion may be due, at least in part, to inhibition of the $\mathrm{Ca}^{2+}$-dependent protein kinase $\mathrm{C}$ isoform.

There are inconsistencies in the various reports for the mechanism by which leptin reduces insulin secretion, but a reduction in the intracellular $\mathrm{Ca}^{2+}$ concentration is a consistent observation.

The role of the leptin signalling pathway in the action of leptin on insulin secretion is obscure. The leptin receptor is closely related to the type-1 superfamily of cytokine receptors. To date, studies in vivo on leptin signalling have been restricted to a STAT-3-dependent satiety mechanism in the leptin-deficient $o b / o b$ mouse hypothalamus (Vaisse $e t$ al. 1996). No activation of hypothalamic STAT-3 occurred in the $d b / d b$ mouse. In cell lines and over-expression studies, leptin has been shown to activate the JAK-STAT transduction system and the mitogen-activated protein kinase signalling pathways (Takahashi et al. 1996). We (Islam et al. 1997) have shown that leptin can activate tyrosine phosphorylation and induction of the early gene $c$-fos in the pancreatic islet cell line RIN m5f. It has been shown also that subchronic treatment $(6-12 \mathrm{~h})$ of rat islets with leptin leads to both a reduction in insulin secretion and a reduction in insulin mRNA (Kulkarni et al. 1997; Pallett et al. 1997). Thus, it would appear that leptin has both an immediate action on insulin secretion and a long-term action to reduce the insulin mRNA. A challenge in islet research is to define the mechanisms whereby leptin exerts these discrete responses.

\section{Effects of leptin on glycogen synthesis in muscle}

Skeletal muscle is the major site of insulin-mediated glucose uptake in animals and man, and defective glycogen synthesis in muscle is one of the earliest manifestations of insulin resistance. Since insulin resistance is associated with obesity, which in turn is associated with an increased secretion of leptin from adipose tissue, we examined the direct effect of leptin on glycogen synthesis in muscle (Liu et al. 1997). Recombinant murine leptin at 10 and $100 \mathrm{nmol} / 1$ inhibited glycogen synthesis in soleus muscle of $o b / o b$ mice in the presence of physiological concentrations of insulin (Fig. 4), but had no significant effect on glycogen synthesis in muscles from either wild-type or $d b / d b$ mice. The lack of a significant effect of leptin in muscle of wild-type mice did not appear to be related to receptor expression level, since quantitative polymerase chain reaction amplification studies showed a similar level of expression of both $\mathrm{OB}-\mathrm{Rb}$ and all isoforms of OB-R between $o b / o b$ and wild-type mice.

Studies to examine the effect of leptin on food intake and body-weight changes have also shown that $o b / o b$ mice are the most sensitive animals to the effect of leptin, and reduced responsiveness to leptin is common in lean animals and in animals that fail to resist the obesity-inducing effects of a high-fat diet.

\section{Contrasting central and peripheral effects of leptin on glucose metabolism}

Kamohara et al. (1997) examined the effects on glucose turnover and glucose utilization of intravenously- and 
intracerebroventricularly-administered infusions of leptin into wild-type mice. Measurements were made 3-5 h after commencing the infusion. Both treatments resulted in a reduction in the plasma insulin concentration $(\mathrm{ng} / \mathrm{ml}$; controls 1.5 , intravenous leptin 0.8 , intracerebroventricular leptin 1.1), but produced a significant increase in glucose turnover $(\mathrm{mg} / \mathrm{kg}$ per min; controls $15 \cdot 0$, intravenous leptin 23.7, intracerebroventricular leptin 21.8). These findings suggest that leptin increases both glucose output and glucose uptake (probably from liver, as liver glycogen content decreased) independent of increases in plasma insulin.

In addition to increased whole-body glucose turnover, glucose uptake into skeletal muscle and brown adipose tissue was significantly increased in the leptin-treated mice. As intracerebroventricular leptin was more potent but produced the same range of effects as intravenous leptin, then it seems likely that efferent signals from the central nervous system modulated glucose metabolism in these mice. The possibility that neuronal signals were responsible was further tested by comparing denervated and intact muscle in the same animals. The action of leptin on muscle glucose uptake in vivo was blocked by denervation, supporting the notion that these actions of leptin are dependent, at least in part, on neuronal signals.

These findings taken together with our own findings suggest that leptin affects glucose metabolism in muscle both directly through muscle OB-Rb and via stimulation of neural (probably sympathetic) pathways. The action of these two pathways, involving inhibition of glycogen synthesis and stimulation of glycolysis respectively, would have the effect of shifting glucose metabolism from storage to oxidative.

\section{Could leptin be diabetogenic?}

It is now well established that obese subjects are insulin resistant and have an increased risk of developing noninsulin-dependent diabetes. Circulating levels of leptin increase with adiposity (Considine et al. 1996). Obese subjects do not present with non-insulin-dependent diabetes until they develop a relative insulin secretion deficit, i.e. their rate of insulin secretion fails to meet the increased insulin requirement that results from their insulin-resistant state. Our twin findings from in vitro studies show that relatively high concentrations of leptin will inhibit glycogen synthesis in muscle and reduce insulin secretion from pancreatic islets, suggesting that leptin might be one of the triggers that causes the development of non-insulin-dependent diabetes. This notion is further supported by the finding by Kulkarni $e t a l$. (1997) that leptin administration to normal and $o b / o b$ mice resulted in a marked lowering of plasma insulin and a doubling of plasma glucose. These actions of leptin could be part of a process to increase catabolic activity in obese animals and man.

\section{Acknowledgements}

The authors thank Amber Kanu, David Hislop and Pat Randall for technical assistance and Julie Cakebread for secretarial assistance. The authors are grateful to Dr Jon Arch,

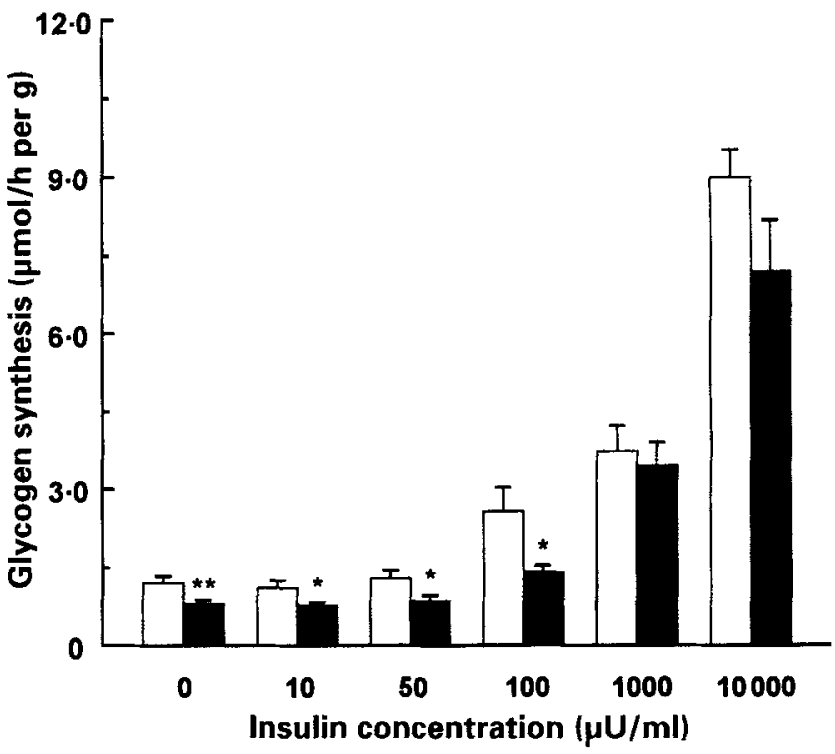

Fig. 4. Effect of leptin ( $100 \mathrm{nmol} / \mathrm{l} ; \boldsymbol{w})$ on glycogen synthesis in soleus muscle of 8-10-week-old ob/ob mice. (ㅁ), PBS-treated controls. Values are means with their standard errors represented by vertical bars. Mean values were significantly different from those for controls treated with PBS: ${ }^{*} P<0.05,{ }^{* *} P<0.01$.

SmithKline Beecham, Harlow, Essex, UK, for providing the recombinant leptin used in some of the studies.

\section{References}

Baumann H, Morella KK, White DW, Dembski M, Barton PS, Kim H, Lai C-H \& Tartaglia LA (1996) The full-length leptin receptor has signalling capabilities of interleukin 6-type cytokine receptors. Proceedings of the National Academy of Sciences USA 93, 8374-8378.

Campfield LA, Smith FJ, Guisez Y, Devos R \& Burn P (1995) Recombinant mouse $\mathrm{OB}$ protein: evidence for a peripheral signal linking adiposity and central neural networks. Science 269, 546-549.

Chen H, Churfat O, Tartaglia LA, Woolf EA, Wang X, Ellis SJ, Lukey ND, Culpepper J, Moore KJ, Breitbart LF, Duyk GM, Tepper RL \& Morgenstern JP (1996) Evidence that the diabetes gene encodes the leptin receptor: identification of a mutation in the leptin receptor gene in $d b / d b$ mice. Cell 84, 491-495.

Considine RV, Sinha MK, Heiman ML, Driauciunas A, Stephen TW, Nyce MR, Ohannesian JP, Marco CC, McKee LL, Bauer TL \& Caro JF (1996) Serum immunoreactive leptin concentrations in normal weight and obese humans. New England Journal of Medicine 334, 292-295.

Easom RA, Hughes JH, Landt M, Wolf BA, Turk J \& McDaniel ML (1989) Comparison of the effects of phorbol esters and glucose on protein kinase $\mathrm{C}$ activation and insulin secretion in pancreatic islets. Biochemical Journal 264, 27-33.

Emilsson V, Liu Y-L, Cawthorne MA, Morton NM \& Davenport M (1997) Expression of the functional leptin receptor mRNA in pancreatic islets and direct inhibitory action of leptin on insulin secretion. Diabetes 46, 313-316.

Fehmann HC, Bode HP, Ebert T, Karl A \& Göke B (1997a) Interaction of GLP-1 and leptin at rat pancreatic $\beta$-cells: effects on insulin secretion and signal transduction. Hormone and Metabolic Research 29, 572-576. 
Fehmann HC, Peiser C, Bode HP, Stamm M, Staats P, Hedetoft C, Long RE \& Göke B (1997b) Leptin: a potent inhibitor of insulin secretion. Peptides 18, 1267-1273.

Halaas JL, Gajiwala KS, Maffei M, Cohen SL, Chait BT, Rabinowitz D, Lallone RL, Burley SK \& Friedman JM (1995) Weight reducing effects of the plasma protein encoded by the obese gene. Science 269, 543-546.

Islam MdS, Morton NM, Hanssen A \& Emilsson V (1997) Rat insulinoma-derived pancreatic $\beta$-cells express a functional leptin receptor that mediates a proliferative response. Biochemical and Biophysical Research Communications 238, 851-855.

Kamohara S, Burcelin R, Halaas JL, Friedman JM \& Charron MJ (1997) Acute stimulation of glucose metabolism in mice by leptin treatment. Nature 389, 374-377.

Kieffer TJ, Heller RS \& Hebener JF (1996) Leptin receptors expressed on pancreatic islets. Biochemical and Biophysical Research Communications 224, 522-527.

Kieffer TJ, Heller RS, Leech CA, Holz GG \& Hebener JF (1997) Leptin suppression of insulin secretion by the activation of ATP-sensitive $\mathrm{K}^{+}$-channels in pancreatic $\beta$-cells. Diabetes $\mathbf{4 6}$, 1087-1093.

Kulkarni RN, Wang ZL, Wang RM, Hurley JD, Smith DM, Ghatei MA, Withers DJ, Gardiner JV, Bailey CJ \& Bloom SR (1997) Leptin rapidly suppresses insulin release from insulinoma cells, rat and human islets and, in vivo, in mice. Journal of Clinical Investigation 100, 2729-2736.

Leclercq-Meyer V, Considine RV, Sener A \& Malaisse WJ (1997) Do leptin receptors play a functional role in the endocrine pancreas? Biochemical and Biophysical Research Communications 229, 794-798.

Lee GH, Proenca R, Montez JM, Carroll KM, Darvishzadeh JG, Lee JL \& Friedman JM (1996) Abnormal splicing of the leptin receptor in diabetic mice. Nature 379, 632-635.

Levin N, Nelson C, Gurney A, Vandlen R \& De Sauvage F (1996) Decreased food intake does not completely account for adiposity reduction after ob protein infusion. Proceedings of the National Academy of Sciences USA 93, 1726-1730.

Liu Y-L, Emilsson V \& Cawthome MA (1997) Leptin inhibits glycogen synthesis in the isolated soleus muscle of obese $(o b / o b)$ mice. FEBS Letters 411, 351-355.

Nakashima K, Narazaki M \& Tuga T (1997) Overlapping and distinct signals through leptin receptor $(\mathrm{OB}-\mathrm{R})$ and a closely related cytokine signal transducer gp 130. FEBS Letters 403, 79-82.

Ookuma M, Ookuma K \& York DA (1998) Effects of leptin on insulin secretion from isolated rat pancreatic islets. Diabetes $\mathbf{4 7}$, 219-223.

Ookuma M, York DA \& Bray GA (1997) The suppressive effects of enterostatin on various stimuli for insulin secretion in pancreatic islets. FASEB Journal 11, A297.
Pallett A, Morton NM, Cawthorne MA \& Emilsson V (1997) Leptin inhibits insulin secretion and reduces insulin mRNA levels in rat isolated pancreatic islets. Biochemical and Biophysical Research Communications 238, 267-270.

Pelleymounter MA, Cullen MJ, Baker BM, Hecht R, Winter D, Boone T \& Collins F (1995) Effects of the obese gene product on body weight regulation in $o b / o b$ mice. Science 269, 540-543.

Prevaskaya NB, Skryma RN, Vacher P, Daniel N, Djione J \& Duby $B$ (1995) Role of tyrosine phosphorylation in potassium channel activation - functional association with prolactin receptor and JAK2 tyrosine kinase. Journal of Biological Chemistry 270, 24292-24299.

Surwit RS, Kuhn CM, Cochrane C, McCubbin JA \& Feinglos MN (1988) Diet-induced type 2 diabetes in C57BJ/6J mice. Diabetes 37, 1163-1167.

Takahashi Y, Okimura Y, Mizuno I, Takahashi T, Kaji H, Uchiyoma T, Abe H \& Chihara K (1996) Leptin induces tyrosine phosphorylation of cellular proteins including STAT-1 in human renal adenocarcinoma cells, ACHN. Biochemical and Biophysical Research Communications 228, 859-864.

Tartaglia LA, Dembeki M, Weng X, Deng N, Culpepper J, Devos R, Richards GJ, Campfield LA, Clark FT, Deeds J, Muir C, Sankey S, Moriaty A, Moore KJ, Smutko JS, Mays GG, Woolf FA, Munroe CA \& Pepper RL (1995) Identification and expression cloning of a leptin receptor, OB-R. Cell 83, 1263-1271.

Vaisse C, Holaas JL, Harvath CM, Darnell JE Jr, Stolfel M \& Friedman JM (1996) Leptin activation of STAT3 in the hypothalamus of wild-type and $o b / o b$ mice but not $d b / d b$ mice. Nature Genetics 14, 95-97.

Wencel HE, Smother C, Opara EC, Kuhn CM, Feinglos MN \& Surwit RS (1995) Impaired second phase insulin response of diabetes-prone C57BI/6J mouse islets. Physiological Behaviour 57, $1215-1220$.

White DW, Kuropatwinski KK, Devos R, Baumann H \& Tartaglia LA (1997) Leptin receptor (OB-R) signalling-cytoplasmic domain mutational analysis and evidence for receptor homooligomerisation. Journal of Biological Chemistry 272, 4065-4071.

Yada T, Russo LL \& Sharp GWG (1989) Phorbol ester-stimulation insulin secretion by Rin m5f insulinoma cells is linked with membrane depolarisation and an increase in cytosolic free $\mathrm{Ca}^{2+}$ concentration. Journal of Biological Chemistry 264, 2455-2462.

Yu WH, Kimura M, Walczewska A, Karanth S \& McCann SM (1997) Role of leptin in hypothalamic pituitary function. Proceedings of the National Academy of Sciences USA 94, 1023-1028.

Zhang Y, Proenca R, Maffei M, Barone M, Leopold L \& Friedman JM (1994) Positional cloning of the mouse obese gene and its human homologue. Nature 372, 425-432. 